\title{
MOVE YOUR AVATAR! Improvisational Theatre Methods in Virtual Teams
}

\author{
http://dx.doi.org/10.3991/ijac.v8i4.4843 \\ Stefanie Quade \\ Berlin School of Economics and Law, Berlin, Germany
}

\begin{abstract}
The importance of a process for a successful start of a new project team is common in business management. Warming up and cooling down exercises are already well accepted methods to activate learning groups. Improvisational theatre has become very popular during the last years as one of these activating practices. Compared to real life settings, meetings in avatar-based, 3-dimensional virtual environments suffer from various communication issues there is no body language, no gestures or mime you could see in the face of an avatar. To increase the interactivity of virtual avatar groups, face-to-face best practices of improvisational theatre methods were transferred into virtual 3D course sessions at the Berlin School of Economics and Law. The impact of these extemporaneous exercises on the interactivity and team performance during the virtual sessions was observed using the participatory action research method (PAR). The transferability of successful real life settings into a virtual 3D course was analyzed. The paper recommends the top improvisational theatre trainings and their impact on the interactivity and team building outcome.
\end{abstract}

Index Terms - 3D course, avatar, improvisation theatre game, virtual collaboration.

\section{INTRODUCTION}

Virtual collaboration has become more and more popular in the last years - even in education or in the workplace. In $201179 \%$ of U.S. workers could imagine to work from home, appr. 64 Mio. U.S. employees hold a job where at least part of the time a virtual workplace would be possible [1]. Organizations made up different approaches for efficient group work and figured out how to adopt best practices into virtual settings. Next to this it has also become more popular to go away from hierarchically structured meetings to collaborative teams, using the full power of all team members and respect each other different pieces of meaning he or she gives in to bake the cake. Meeting in real person, meeting in time-displaced blended settings like blogs and meeting in virtual real-time like adobe connect or immersive 3D environments like second life ${ }^{\circledR}$ or LibertasU [2]. - all have their advantages and challenges. Erenli (2011) provides an overview and scoring model for learning and teaching in $3 \mathrm{D}$ worlds on the VICERO platform [3].

$93 \%$ of a conversation is communicated by non-verbal content [4]. In virtual environments the non-verbal elements are limited. Whenever you don't meet in real person, the lack of personal face-to-face communication is a gap that has to be overcome in all other virtual variations of get-togethers. To onboard virtual teams it is essential to emphasize the interpersonal dynamics of virtual collaboration and establish practices for team building [5]. This increases the team transparency and enhances personal relationships to empower a productive virtual team.

\section{A. Improvisational theatre games}

To activate communication, improvisational theatre games can be integrated at the beginning or end of a team setting. A lot of improvisational theatre games can be found online (e.g. [6], [7]). Skills and processes of improvisation are used as an educational tool and in businesses as a way to develop communication skills, creative problem solving and supportive teamwork abilities that are used by improvisational, ensemble players [8]. The improv players follow some rules to have an ongoing interactivity: "don't hesitate, pay attention, never block or negotiate, always add something positive, don't be scared of silence" [9]. This paper focuses on the transfer of these improvisational elements from real life settings into virtual team sessions.

\section{B. Virtual 3D Learning - Practice Supervision}

In our investigation we decided to use a 3D learning environment to test the virtual improvisation theatre. Since 2010 the Berlin School of Economics and Law (BSEL) teaches - on the initiative of Prof. Marcus Birkenkrahe - a practice supervision course in virtual 3D worlds [10]. As part of the bachelor degree 'International Business Management' (IBMAN) the students have to conduct an internship at the end of their studies, normally in the $6^{\text {th }}$ semester. All students participate in the online session in form of avatars, which digitally represents the participant's body [11]. The main learning objectives of the course are to share the workplace experiences, professionalize the communication, get coaching and give feedback to each other (see fig. 1).

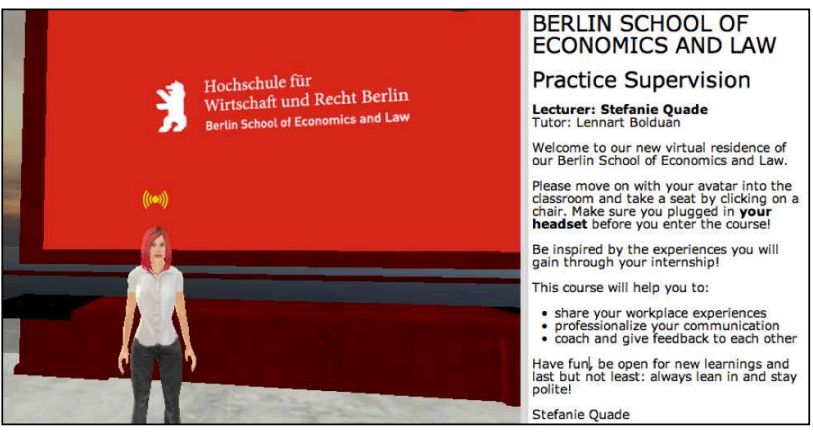

Figure 1. Practice Supervision Course in 3D Virtual Class

To reach the targets, students meet on a weekly basis for 90 minutes live in the 3D environment. The course responds to the demand of the students working in different time zones by offering a virtual lunch and evening session. Course participants are distributed in their intern- 
ships worldwide and enter not only geographically but also professionally, interpersonally and intercultural uncharted territory. They work in various located companies across the world. The practice supervision course, which is a 5 credits course with 4 semester periods per week, takes place on parallel during their internship term. They report on their work experience and reflect on one topic of the class (e.g. dealing with negative people, networking, culture at work, dress code, etc.) in a weekly blog post using the learning management system Moodle of the university.

Fig . 2 shows a classroom situation of the virtual BSEL with very similar looking avatars. Only the verbal communication creates individual perception among themselves.

In the virtual class each students present their internship in form of a few slides. One major part of each virtual session is to practice role play with the students. The students pick one situation they observed or they want to solve and describe the role play situation at the end of their presentation. Through the immersion effect role plays work really well in 3D environments, students feel less embarrassed to slip into roles as observed an evaluated by Birkenkrahe [10]. The concentration on the spoken word is one big advantage of role playing with avatars. Students focus on the conversation, build arguments and learn to deal with problem situations in an assertive way (see fig. 3).

Besides many benefits the virtual BSEL offers, like the immersion effect, meeting despite global distribution, etc. it has been criticized that the learning environment the active participation - for both students and teachers - in 3D settings perceived as insufficient ("technical problems", "Avatar falls asleep after a few minutes", "no emotions/reactions"). One conclusion was the change from Second Life to a new collaboration with "LibertasU", a North-American 3D vendor. One advantage of this platform is a browser-based application (a software installation like Second Life is not needed). Another step was the investigation in engaging the interactivity between the students using their avatars, which is virtually particularly important and sometimes more difficult to achieve.

But the challenges for a personal communication are: there is no body language, no gestures or mime you could see in the face of an avatar in LibertasU. To overcome this gap, in the last winterterm 2014/15 improvisation theatre methods were tested in the virtual sessions, to engage the students to interact in a more open way and prepare them for their role play.

\section{Why do we need improv games for $3 D$ learning?}

So far, no improvisational theatre methods have been tested in the virtual BSEL. The interdisciplinary approach, to use theatre arts methods for team-building and team performance has already been successfully anchored in business. Scinto, a lecturer in Columbia University's strategic communications programs, summarizes why improv training improves communication: "They must be present in the moment, listening carefully, and contributing freely. These skills turn out to be particularly useful in workplaces that rely on adaptability" [12]. This, however, embedded in a virtual learning environment with limited emotional, physical expression possibilities of avatars is a new approach.

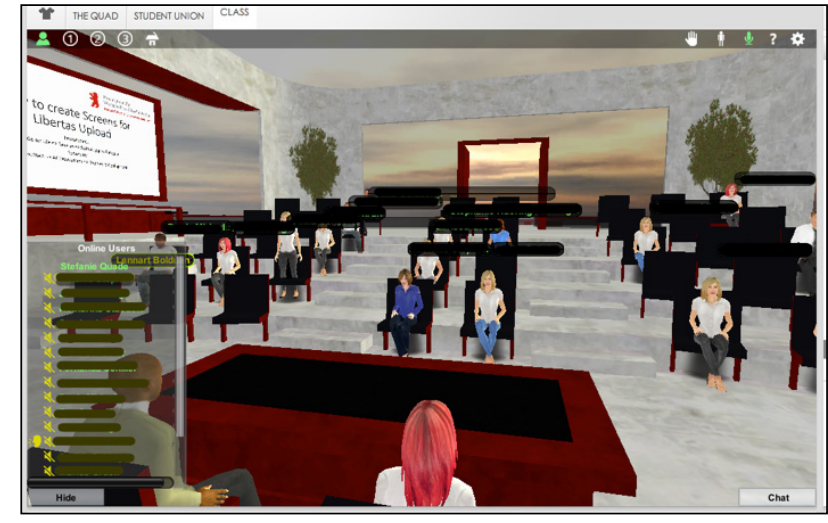

Figure 2. Start of a typical virtual session with avatars

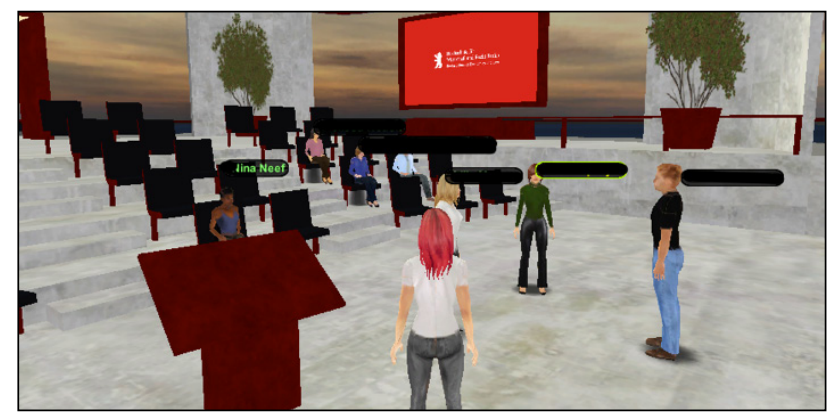

Figure 3. Role play situation, teacher coaches students business case

The experience in the $3 \mathrm{D}$ course has shown that through the immersion effect students showed "in their virtual identity" more openness in role-playing games in assertiveness training. The investigation in this paper is to find out, if improv theatre methods can intensify the interactivity and increase communication skills in student's role plays and presentations.

The following research questions are addressed to find a solution to overcome the identified gap of communication:

1.) What enables all participants to strengthen the "team spirit" in the virtual world by overcoming the lack of visibility of emotions (eye contact, gestures, facial expressions, etc)?

2.) Do improvisational theatre methods improve the interactivity between student's avatars in the 3D environments?

\section{INNOVATIVE LEARNING \& TEACHING INITIATIVE}

The BSEL provided the exchange of different teaching expertise during a whole study term with an educational 'fresh cells' project. The university supports here a tandem-teaching concept, where a second co-teacher brings his/her expertise in the course and visa versa.

The decision to use improvisational methods for the virtual 3D course has been invented by the successful use in real project teams of the two teachers involved in the improvisational theatre game project, both in education and also in real project teams. The virtual collaboration and supervision teaching experience combined with the improv theatre coaching experience - through the author in collaboration with Nina Neef.

The 'fresh cells' initiative is part of the BSEL "Blended Learning - measures to further optimize the conditions for 
studying and developing innovative study models". This innovative experiment addresses these measures:

- $\quad$ by using transferable, electronically supported methods to increase the effectiveness of individual teachers sustainably;

- $\quad$ to position the use of new media and contemporary forms of mediation as a standard and thereby raise the profile of the university.

The approach to integrate improvisational theatre games in 3D learning environment has been accepted by the board of the BSEL 'fresh cells' initiative as project with highly innovative potential.

\section{METHODS}

To measure the impact of the improv games on the interactivity and communication of the practice supervision course, the following methods have been applied. Improvisational methods have been conducted and evaluated over a period of 10 weeks within one term of the practice supervision course throughout participatory action research (PAR) [13].

The whole practice supervision team, including the teacher and guest lecturer, participated at the improv games (P). Each game has been exercised (A) and the results have been researched (R) and analyzed (fig. 4).

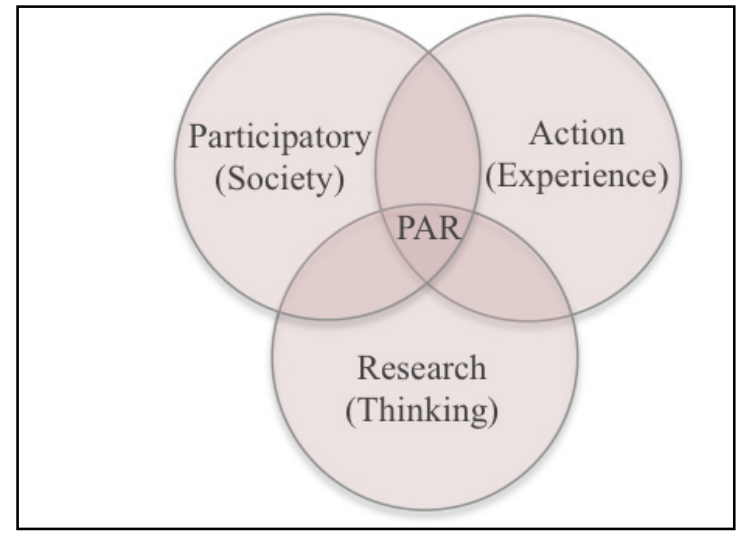

Figure 4. Participatory Action Research, own image based on [13].

The following steps have been conducted:

\section{A. Selection of improvisational theatre games}

The first step of this investigation is to select suitable improvisational theatre games for the practice supervision course. The criteria for the selection are the accuracy of fit and the feasibility for the course objectives. Limiting factors like technical issues have to be taken into consideration.

\section{B. Performance of improvisational theatre games}

The second step of this investigation is to participate and exercise the improv games in the weekly courses. The observation of the performance has been recorded directly after each session by the two tandem teachers - by writing or graphic recording.

\section{Analyzis of improvisational theatre games}

In the third step the recorded data are researched and the impact on interactivity and team building analyzed.

\section{RESUlTS}

The course took place at two different times: lunch session and evening session - the group size of the lunch session was 5-10 participants, the evening session 10-20 participants. The 26 students can choose, which session they take. Improv units have been integrated in $2 \times 10$ online sessions (each 90 minutes).

The IBMAN practice supervision course in the winter term 2014/2015 contained the following weekly topics, one in each parallel session:

$\begin{aligned} \# 1 & \text { Introduction to the course } \\ \# 2 & \text { Talking \& communicating } \\ \# 3 & \text { (Non-) Assertiveness } \\ \# 4 & \text { Assertiveness } \\ \# 5 & \text { Dealing with negative people } \\ \# 6 & \text { How to make stress your friend } \\ \# 7 & \text { Dress code \& body language } \\ \# 8 & \text { Culture at work } \\ \# 9 & \text { Networking } \\ \# 10 & \text { Knowledge management }\end{aligned}$

\section{A. Selection of improvisational theatre games}

Before the course both lecturers decided which improv games are suitable for each weekly supervision topic. Technical limitations were taken into consideration. The conditions of the virtual room, the movement limits of the avatar - e.g. in the body of an avatar at LibertasU can walk, run, jump, clapp hands, use voice and chat. But more complex expressions are excluded - it is impossible to smile, look grumpy, move arms unique or to take a bow. Here, a high transfer performance is needed, since the lack of facial expressions, gestures and emotional response in the virtual world must be adapted to the limited possibilities of avatars. Surrogate activities / intensive communication solutions were identified and applied with the avatars in advance.

For the improv theatre methods to really achieve their purpose, they need to be planned and practiced beforehand: the preparation required the amount of a few hours of conceptual work for both lecturers. Stefanie Quade embedded these weekly didactically into the virtual learning environment. They proofed each improv unit in advance on their suitability for the virtual session.

\section{B. Performance of improvisational theatre games}

Table I explains each improv unit related to the weekly course topic (\#). All exercises are described and the related learning objectives are presented.

Each improv unit was exercised at the beginning of the session with a duration of appr. 5-10 minutes.

The improvisation theatre units, which have been exercised, are examples, picked out from the experience of the two teachers and adapted to the session topics (\#). Most of them can be found online, sometimes with slightly different titles.

Next to the written notes before and after each session, graphic recorded notes also enriched the documentation for the analysis (see fig. 5) 
PAPER

MOVE YOUR AVATAR! IMPROVISATIONAL THEATRE METHODS IN VIRTUAL TEAMS

TABLE I.

IMPROV UNITS CONDUCTED AT THE BSEL IBMAN SUPERVISION COURSE, OWN IMAGE AND CONTENT BY STEFANIE QUADE \& NINA NEEF

\begin{tabular}{|c|c|c|c|}
\hline & Improv unit & Exercise & Learning objective \\
\hline$\# 1$ & $\begin{array}{l}\text { Animal game, } \\
\text { association circle }\end{array}$ & $\begin{array}{l}\text { Students stand in a circle, everybody introduces his-/herself as } \\
\text { an animal + typical adjective which fits to themselves }\end{array}$ & $\begin{array}{l}\text { Self-awareness, realizing strengths, activating creativ- } \\
\text { ity, name-animal-picture-association, move avatar in a } \\
\text { circle, voice checking, introduction of participants }\end{array}$ \\
\hline \#2 & Childhood dream & $\begin{array}{l}\text { Everybody tells the group, which job he/she wanted to get as a } \\
\text { child }\end{array}$ & Storytelling, activation, presentation techniques \\
\hline \#3 & $\begin{array}{l}\text { Disaster, yes and } \\
\text { game }\end{array}$ & $\begin{array}{l}\text { Pair of } 2 \text { in rows, the first is telling a disaster, the second } \\
\text { increases this by "yes and" the first finds a solution for the } \\
\text { disaster }\end{array}$ & $\begin{array}{l}\text { Active listening, practice fast communication, find } \\
\text { quick solutions, teamwork }\end{array}$ \\
\hline \#4 & Fairytale story & $\begin{array}{l}\text { Participants stand in a row, the first starts a fairytale story and } \\
\text { is interrupted (by the improv director) by calling a name of } \\
\text { another participant, the called participant must continue to tell } \\
\text { the story without interruption until it is again interrupted, etc. }\end{array}$ & Creativity, storytelling, stress management \\
\hline \#5 & Yesyesyes & $\begin{array}{l}\text { Everybody names a learning out of the session - all confirm } \\
\text { this together with "yes yes yes" }\end{array}$ & Consolidate team and content, team activity \\
\hline \#6 & 4-6-8 breathing & Breath training: 4 times inhale, 6 times hold, 8 exhale & Stress reduction \\
\hline \#7 & Apple tree & $\begin{array}{l}\text { Association circle, topic clothes. First participant starts with } \\
\text { "trousers" second complements the look with "t-shirt", the } \\
\text { third gets in the circle and associates "hat". The rest decides } \\
\text { what fits best "I take the hat with me". The one left starts with } \\
\text { a participant and new association, etc. }\end{array}$ & Communication and association training \\
\hline \#8 & Abc story & $\begin{array}{l}\text { Participants buildt sentences starting with "a", the next one } \\
\text { "b", etc. regarding the topic: culture at work }\end{array}$ & $\begin{array}{l}\text { Fast associating and communication game regarding } \\
\text { "culture at work" }\end{array}$ \\
\hline \#9 & Mirror & $\begin{array}{l}\text { Participants mirror each other. One acts first, the other "mir- } \\
\text { rors" the activities }\end{array}$ & Move your avatar, activating, networking \\
\hline$\# 10$ & Body scan & $\begin{array}{l}\text { Scan your body in a mental way from top to bottom - be aware } \\
\text { of your tasks and responsibilities in your job and your career }\end{array}$ & Self-awareness, stress reduction \\
\hline
\end{tabular}

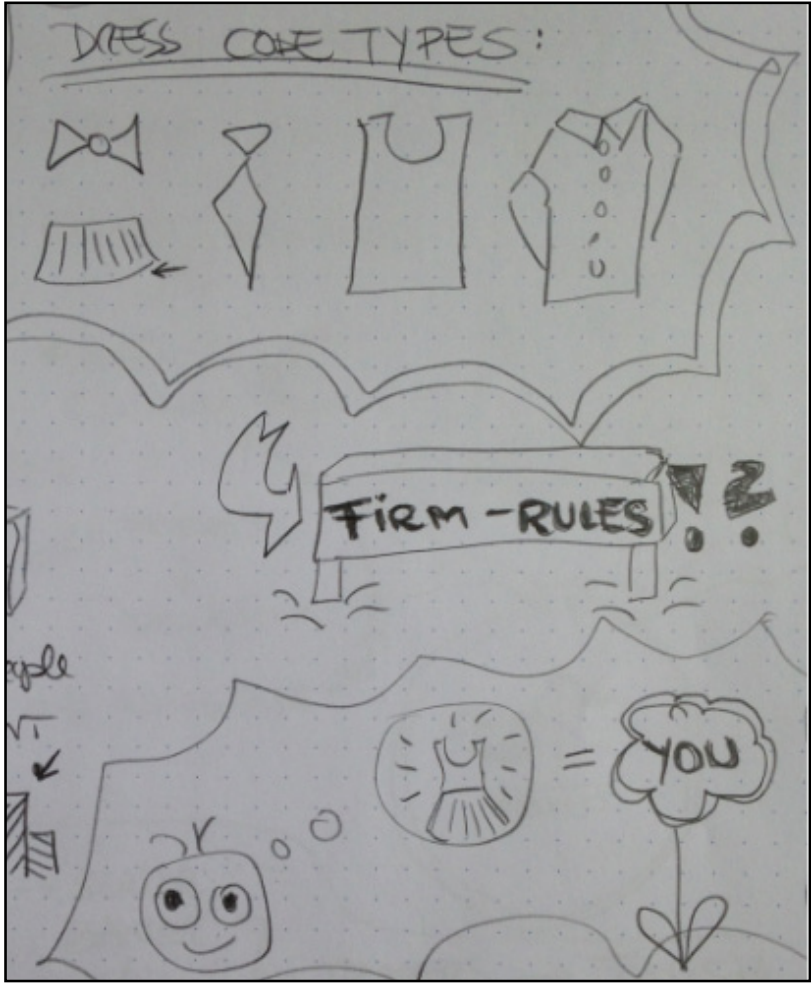

Figure 5. Graphic recording of the session \#7 dress code by Nina Neef

\section{Analyzis of improvisational theatre games}

At the end of the course all session documentations have been analyzed. What went well, what went bad? Next to each unit (\#1-10 weekly session topic) the learnings are documented. How is the impact on interactivity and team building? Next to the learnings the overall impact has been categorized by using ( ++ for very high impact, + high impact, - low impact, -- no impact) for each improv unit (see Table II).

Starting from the point that the tandem teachers just picked improv exercises, which was successfully tested in real class room situations, the analysis shows the highs and lows.

Improv exercises \#1 (weekly topic: introduction to the course, improv unit: animal game), \#2 (weekly topic: talking and communicating, improv unit: childhood dream) and \#3 (weekly topic: (non-) assertiveness, improv unit: disaster, yes and game) activated the group very highly. The participants were really engaged in their storytelling. In the first three sessions the student had to deal with the technical obstacles, trained to move their avatar, improv their audio settings (buy an USB-headset). This caused some delays in the improv game and mad the game sometimes not fluent enough. But overall theses three games had a very high impact on interactivity and teambuilding and made the course start more engaged compared to the previous course.

Units \#4, \#7, \#8 and \#9 still had a good impact on the team and with some minor changes (e.g. concrete example for a fluent start and fast play) these games could be useful for the virtual sessions.

The units with just a low or no impact for the virtual settings are still useful games for real life settings, but not in the $3 \mathrm{D}$ environment. \#5 works good in real class room sessions, because of the bowing body and folded hands, not suitable for virtual settings. \#6 is good mental training, but not visible and useful for virtual settings. \#10 is a good mental training, contracting on trainings with "spoken words", but not in the virtual 3D world. 
PAPER

MOVE YOUR AVATAR! IMPROVISATIONAL THEATRE METHODS IN VIRTUAL TEAMS

TABLE II.

IMPROV UNITS CONDUCTED AT THE BSEL IBMAN SUPERVISION COURSE, OWN IMAGE AND CONTENT BY STEFANIE QUADE \& NINA NEEF

\begin{tabular}{|c|c|c|c|}
\hline & $\begin{array}{l}\text { What went well } \\
\text { (2) }\end{array}$ & $\begin{array}{c}\text { What went badly } \\
\text { : }\end{array}$ & $\begin{array}{c}\text { Impact on interactivity } \\
\text { and team buildung } \\
++/+/---\end{array}$ \\
\hline$\# 1$ & $\begin{array}{l}\text { Participant constellation, creativity (animal + adjec- } \\
\text { tive), associations }\end{array}$ & Speaking after each other, who's next? & ++ \\
\hline$\# 2$ & $\begin{array}{l}\text { Stories, good reflection on past childhood dreams and } \\
\text { present }\end{array}$ & Order, who's next? & ++ \\
\hline \#3 & Pair of 2 in lines, "yes, and" tactic & $\begin{array}{l}\text { Budge over so that the next pair builds the front line } \\
\text { with their avatars }\end{array}$ & ++ \\
\hline \#4 & Good story line, interruptions and stress reaction & Sometimes confusing & + \\
\hline$\# 5$ & Everbody mentioned a learning & No avatar body movement, too slow interactions & - \\
\hline \#6 & $\begin{array}{l}\text { Students used methods e.g. in full subway or in a } \\
\text { stressful workplace situation }\end{array}$ & Imagination, no proof in virtual groups & - \\
\hline \#7 & $\begin{array}{l}\text { Good ideas and associations, fits to the topic "dress } \\
\text { code" }\end{array}$ & Moving of avatars sometimes too slow & + \\
\hline \#8 & Associations & Alphabetical order sometimes confusing, who's next & + \\
\hline$\# 9$ & Students had fun to mirror each other & Less possibilities in the virtual room & + \\
\hline$\# 10$ & $\begin{array}{l}\text { Good relation to the topic body language and } \\
\text { knowledge about yourself and your responsibilities }\end{array}$ & $\begin{array}{l}\text { No spoken words, therefore no "interaction" in the } \\
\text { virtual room }\end{array}$ & - \\
\hline
\end{tabular}

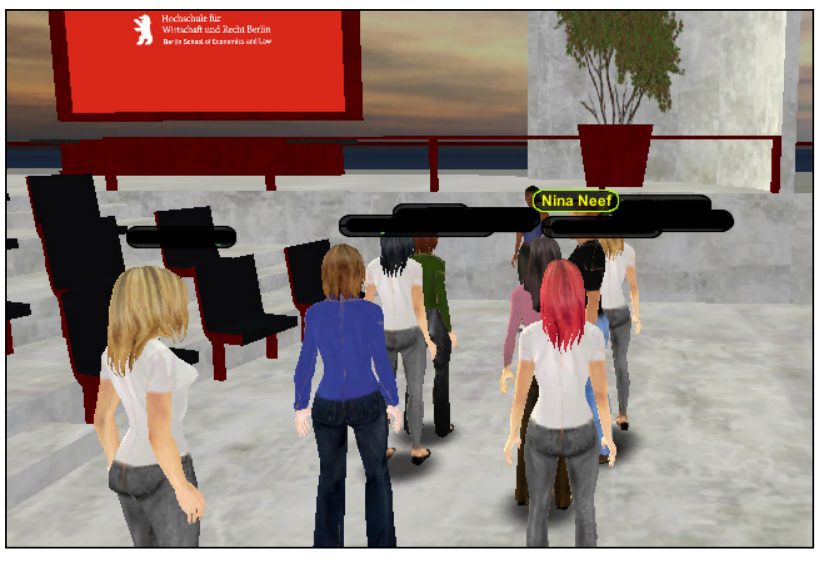

Figure 6. improvisation unit \#3, "disaster, yes and - game", avatars walk in two lines

One example of an improvisational theatre game is shown in fig. 6 . The students started via storytelling as a pair of 2 in rows, the first is telling a disaster, the second amplifies this by "yes and" - the first finds a solution for the disaster. Game ends, the next couple starts. The students practiced here active listening, fast communication, find quick solutions, teamwork.

\section{DISCUSSION}

The Practice Supervision Course has the learning objective to prepare the IBMAN students during their internship in professional situations in various fields. The existing learning objectives of the course have been enriched by applying the improvisational theatre methods. Storytelling-methods enhanced the creative communication techniques. This can be directly connected with the substantive elements of the course such as presentation, roleplay, and assertiveness trainings. The skills trained in this course link directly to the ongoing discussion on expert conferences like the "Global Education and Skills Forum 2015", held in Dubai [14]. Shapiro refers in his Forbes article to the World Economic Forum to "skills such as critical thinking, problem-solving, persistence and curirosity" as the most critical $21^{\text {st }}$ century skills [15].

This publication demonstrates the successes and the limits of the use of improvisational theatre methods in the virtual learning environment. With most improv units the communication and interaction has increased. The learning outcomes were achieved and the students experienced individual consciousness related to their internships. The individual learning goals of students have been integrated by revisiting the personal "workplace situations" that are packaged in the stories. The students reflected of the active and conscious role in the internship. The coaching of the lecturer and the improv exercises in the practice supervision course encouraged active feedback - the students added value, which can be lived directly in practical context.

The objectives of the individual exercises were listed at the beginning of the online virtual session and reflected after passing through the exercises with the students and summarized. A follow-up also took place in the Moodle blog, in which the students answered weekly questions and discussed with their peers in the context of everyday working life.

\section{CONCLUSION}

The tandem teaching team experienced 10 different improvisational games with the students at the beginning of each virtual session.

The overall (existing) learning outcomes of the practice supervision course have been enriched by the improvisational games:

- Be able to evaluate their own learning experiences during the internship

- Understand the value and communication rules of professional feedback

- $\quad$ Present their learning experiences in a virtual group and environment

- Fix their work and learning experiences in writing and have discussed and shared in the team

- Learn problem-solving techniques 
Advanced Learning outcomes and competences were gained through the 'fresh cells' project. By the improvisational theatre methods the communication techniques are deepened. The creation of a common result in a playful manner produces a high acceptance of the results. Sharing thoughts made easy and accepting experienced, since these are the basic rules of improv games. The result is a team, a group in which a certain sense of belonging and security arises. The creativity is tapped, the flow of ideas is an opened door. Social skills are trained by the basic assumption of communication deals with the improv exercises. These formats are ideal, the improv theatre relate on communication, acceptance of communicative offers, acceptance, understanding and trust. The creativity of the participants and the communicative playful interaction with each other is increased. It creates a common history or scene.

Especially in virtual courses it is crucial to capture the attention and reaction of the students since direct emotional body language and reactions due to the virtuality are not visible. With the didactic approach to improvisation methods of theatre studies in combination with storytelling methods the goal was to achieve an increase of interaction and communication in the virtual learning environment.

An exchange of virtual with "non-virtual" teacher is a good base here. The barrier to entry into the virtual environment through the tandem exchange via e.g. the 'fresh cells' initiative allows an increase of E-learning at the BSEL. The aim is to transfer to virtual courses not only interdisciplinary exchange between disciplines, topics and methods in other classes. One possible next step could be for example to integrate enterprise projects in virtual courses and deepen cooperation with other universities of applied sciences. In this virtual context it is necessary to ensure an active and professional communication. The improv theatre methods in the virtual learning environment offered a useful tool to overcome the often criticized "passive participation" of the students of the past.

Activating games like improvisational theatre should be integrated into the virtual life, to give attention to the already available content. These methods are very entertaining. The stimulating "packaging" of information leads to a playful simple knowledge building. These forms are accepted in the target group and open up new opportunities for knowledge transfer.

\section{ACKNOWLEDGMENTS}

Special thanks go to Nina Neef, who joined the virtual class as co-teacher and stimulated the communication skills of the students with her improvisational theatre expertise. Acknowledgment goes to Marcus Birkenkrahe, the creator of the practice supervision course, whose E-learning and coaching knowledge made this course possible for the IBMAN students, who practice their internship worldwide abroad and get the chance to meet and share experiences in the virtual sessions during their practice supervision term. Lennart Bolduan with his technical support and Carlye Birkenkrahe with her assertiveness coaching enriched the virtual sessions in the winterterm $2014 / 2015$.

\section{REFERENCES}

[1] Global Workplace Analytics (2012), Telecommuting Statistics, How Many People Could Telework? / How Many Want To? Retrieved on 20 march 2015 from http://globalworkplaceanalytics.com/telecommuting-statistics

[2] Goldberg, J. (2014), Welcome to the LibertasU learning blog, $\begin{array}{lllll}\text { Retrieved on } 20 & \text { march } & 2015 & \text { from }\end{array}$ http://www.libertasu.com/blog.html?id=WP\&page=14

[3] Erenli, K. (2012), Choosing a virtual world platform for teaching - "Vicero" - a scoring modell aiding the right choice, iJAC Vol 5 , nb. 3, retrieved on 20 march 2015 from http://dx.doi.org/10.3991/ijac.v5i3.2192

[4] Mehrabian, A. (2011), Silent Messages - A wealth of information about nonverbal communication (body language), based on original content of 1984. Retrieved on 19 march 2015 from http://www.kaaj.com/psych/smorder.html

[5] Lepsinger, R., DeRosa, D. (2010), Virtual Team Success: A practical guide for working and leading from a distance. San Fransisco, CA, John Wiley \& Sons

[6] Improv Games, Improv Games Collection, Retrieved on 19 march from http://www.improv-games.com

[7] Improv Wiki, Improv Theatre, Retrieved on 19 march from http://improwiki.com/en

[8] Wikipedia, Improvisational Theatre, Retrieved on 20 march from http://en.wikipedia.org/wiki/Improvisational theatre

[9] Franklin, O. (2014) How to improvise stand-up comedy, Wired UK, Culture, Retrieved on 20 march from http://www.wired.co.uk/magazine/archive/2014/04/howto/improv-stand-up

[10] Birkenkrahe, M., Gallo, A. (2011) Transfer Of Physical Classroom Techniques To The Virtual Classroom During a Practice Supervision Course, in: Journal of Virtual Studies March 2011; ISSN: 2155-0107

[11] Wikipedia (2015), Definition Avatar, Retrieved on 19 March 2015 from http://de.wikipedia.org/wiki/Avatar_(Internet)

[12] Scinto, J. (2014), Why improv training is great business training, Forbes, Retrieven on 20 march 2015 from http://www.forbes.com/sites/forbesleadershipforum/2014/06/27/w hy-improv-training-is-great-business-training/

[13] Chevalier, J.M. and Buckles, D.J. (2013) Participatory Action Research: Theory and Methods for Engaged Inquiry, p. 10, Routledge UK. ISBN 978-0415540315. Retrieves on 19 March 2015 from http://www.participatoryactionresearch.net

[14] Global Education and Skills Forum, Conference held in Dubai 15.-16. March 2015, Retrieved on 22 march 2015 from https://educationandskillsforum.org

[15] Shaprio, J. (2015), This year at the 'Davos of Education'. Plus, the 16 most critical $21^{s t}$ century skills, Forbes 22 . March 2015, Retrieved on 23. March 2015 on http://www.forbes.com/sites/jordanshapiro/2015/03/22/this-yearat-the-davos-of-education-plus-the-16-most-critical-21st-centuryskills/

\section{AUTHOR}

Stefanie Quade is with the Berlin School of Economics and Law, Berlin, Germany (e-mail: stefanie.quade@hwrberlin.de). http://about.me/stefaniequade

This article is an extended and modified version of a paper presented at the the International Conference on E-learning in the Workplace 2015 (ICELW'15), held in June 2015, at Columbia University in New York, NY, USA. Manuscript received 25 March 2015. Published as resubmitted by the author 30 November 2015 . 